\title{
Effect of Higher Dietary L-Arginine Supplementation on Chemical Composition of Breast Muscle in Broiler Chicken
}

\author{
A. Sathyapriya ${ }^{1}$, C. Bandeswaran ${ }^{1 *}$, R. Karunakaran ${ }^{1}$ and P. Shamsudeen ${ }^{2}$ \\ ${ }^{1}$ Department of Animal Nutrition, Madras Veterinary College, Tamil Nadu Veterinary and \\ Animal Sciences University, Chennai-600 007, Tamil Nadu, India \\ ${ }^{2}$ Department of Poultry science, College of Poultry production and management, \\ Hosur-07, India \\ *Corresponding author
}

\section{Keywords \\ Broiler chicken, L- arginine, Chemical composition, Breast muscle}

Article Info

Accepted:

10 March 2018

Available Online:

10 April 2018

\section{A B S T R A C T}

The growth in the broiler segment is expected to remain strong due to consumer preference for chicken meat. The live market sales of broiler meat still constitute more than $90 \%$ of total sales volume as most consumers prefer freshly slaughtered chicken meat. Modern commercial broilers have a high capacity for lipid biosynthesis because selection strategies have focused on improved body weight gain, breast yield and feed efficiency. Therefore, finding new means to increase the skeletal muscle growth and to reduce excess fat is important for both human health and poultry production. A new horizon of study towards supplementation with L- arginine is effective for skeletal muscle growth. A total of 150 day old Cobb 400 broiler chicks were randomly allocated to 5 treatment groups viz., $\mathrm{T}_{1}$ (100\% of arginine requirement), $\mathrm{T}_{2}\left(125 \%\right.$ arginine), $\mathrm{T}_{3}$ (175\% arginine), $\mathrm{T}_{4}(125 \%$ arginine for finisher period only) and $\mathrm{T}_{5}(175 \%$ arginine for finisher period only). The aim of this study was to evaluate the effect of higher dietary Arginine supplementation on chemical composition of the breast muscle in broilers and was analyzed on dry matter basis by AOAC standard guidelines. The crude protein content of breast muscle was significantly higher in groups fed with excess arginine from day old to slaughter $\left(\mathrm{T}_{2}\right.$ and $\mathrm{T}_{3}$ ). On the other hand, the fat content of breast muscle was significantly higher only in birds fed $175 \%$ arginine in both starter and finisher period $\left(\mathrm{T}_{3}\right)$ than control and was comparable with $\mathrm{T}_{2}, \mathrm{~T}_{4}$ and $\mathrm{T}_{5}$ treatment groups. Dietary arginine at $75 \%$ more arginine supplementation from the starter phase is recommended for highest intra muscular fat percentage

\section{Introduction}

Arginine, an essential amino acid in birds needed in the starter phase of development after hatching as a supplementary ingredient as they are incapable of synthesizing due to non-functional urea cycle. Birds have the highest requirement of Arg among the studied animals (Ball et al., 2007). Jiao et al., (2010) demonstrated that feeding broiler chicks with $80 \%$ of their arginine requirement from 1 to 42 days led to a significant reduction in breast 
muscle and leg muscle weight and percentages. Moreover, Khajali et al., (2011) also opined that carcass yield and breast meat yield significantly reduced in broilers fed diets deficient in arginine. Fernandes et al., (2009) observed that increase in arginine is crucial for improved muscle development in broilers after 21 days. They also observed the enhancements in breast weight, breast fillet weight and thickness and in myofiber diameter of broiler chickens when they fed with L- arginine at the level of $0.1,0.2$ or $0.3 \%$ from 1 to 21 days of age. In addition to that, Carcass yield, breast and thigh muscle percentage of broilers significantly increased by inclusion of Larginine in the diet at the level of $0.04 \%$ and $0.60 \%$ (Al-Daraji and Salih, 2012).

Chemical composition of breast muscle showed an increase in crude protein, dry matter and fat content of breast muscle by increasing arginine level (Ebrahimi et al., 2014). These chemical composition viz., crude protein, crude fat and dry matter contents of breast muscle of broiler chicks can be evaluated on \% dry matter basis. Therefore, the present study was designed to evaluate the effect of different higher levels of arginine on chemical composition in broiler chicks.

\section{Materials and Methods}

The experiment used completely randomized design consisting of 5 dietary treatments with 3 replicates consisting 10 chicks per replicate. Two types of diets were used over the period of experiment; starter diet was used from 1 to 21 days and finisher diet till the end of the experiment (22-42 days). The control diet consisted $\left(\mathrm{T}_{1}\right)$ of $100 \%$ arginine for starter and finisher period as per the (NRC, 1994) requirement and four treatment groups with $125 \%\left(\mathrm{~T}_{2}\right)$ and $175 \%\left(\mathrm{~T}_{3}\right)$ arginine level compared to control during both starter and finisher periods and $125 \%\left(\mathrm{~T}_{4}\right)$ and $175 \%$ $\left(\mathrm{T}_{5}\right)$ arginine level during finisher period only compared to control. The required amount of L- arginine (free base) extra pure was purchased from Sisco Research Laboratory (SRL). The experimental diet was formulated as per (BIS, 2007). The feed ingredient composition $(\%)$ of the broiler chicken starter diet (0-3 weeks) and finisher diet (4-6 weeks) were depicted in the Table 1 and 2 respectively. On $42^{\text {nd }}$ day of feeding experiment, birds were slaughtered by kosher method and samples of breast muscle, liver and abdominal fat tissues were collected from 10 birds contributing 2 birds per treatment.

\section{Chemical analysis of breast muscle}

Samples of breast meat were taken randomly from each treatment. After mincing, drying, grinding and uniform mixing, crude protein (CP), crude fat and dry matter (DM) contents of breast muscle were analyzed according to the AOAC methods (2005).

\section{Statistical analysis}

Data were analyzed with analysis of variance (ANOVA) as per the procedure of statistical analysis system (SPSS, version 20). When significant differences $(\mathrm{p}<0.05)$ were detected, the multiple range tests were used to separate the mean value. All the percentage values in the study were transformed to their arcsine roots before subjecting to statistical analysis.

\section{Results and Discussion}

The results of the effect of dietary supplementation of L-arginine on chemical composition viz., crude protein, crude fat and dry matter contents of breast muscle of broiler chicks is furnished in Table 3. The crude protein and crude fat percentage were significantly higher $(p<0.05)$ in breast muscle of the birds fed with different levels of Larginine when compared with the control. The 
results of the present study on chemical composition of breast muscle agrees with the findings of $\mathrm{Wu}$ et al., (2011) who showed that adding arginine to the diet for 3 weeks increased carcass crude protein content and fat content in breast muscle and chemical composition of breast muscle showed an increase in crude protein, dry matter and fat content of breast muscle by increasing arginine level (Ebrahimi et al., 2014). There was no significant difference in the dry matter / water content of the breast muscle among all treatment groups.

The formulated broiler chicken starter and finisher diets contained $22 \%$ and $20 \% \mathrm{CP}$ respectively on dry matter basis as per the BIS (2007) specification of broiler chicken feeds. However, BIS (2007) recommended $23 \%$ CP for $1^{\text {st }}$ week of age as pre-starter to broiler chicken. The calculated arginine content in the basal diet of broiler starter and finisher diets were $1.56 \%$ and $1.37 \%$, respectively based on arginine content of feed ingredient used in the experimental diet preparation which was taken as control diet assuming $100 \%$ arginine $\left(\mathrm{T}_{1}\right)$. However, these values were 12-13\% higher than the NRC (1994) and ICAR (2013) recommendation for broiler chicken $(1.39 \%$ and $1.22 \%$ respectively for broiler chick starter feed and finisher feed on dry matter basis).

Arginine is a precursor of the cell-signing molecule nitric oxide. Nitric oxide acts as signaling molecule facilitates the dilation of blood vessel and decrease vascular resistance. Nitric oxide is synthesized from arginine under the enzymatic control of nitric oxide synthase. Muscle growth and functions regulated by nitric oxide or related molecules include force production (excitation contraction coupling), auto regulation of blood flow, myocyte differentiation, respiration and glucose homeostasis (Stamler and Meissner, 2001). Contractile activity and muscle growth greatly increase nitric oxide production in the muscle, and this is likely due to elevated intracellular calcium (Kobzik et al., 1994; AlDaraji et al., 2011).

The birds fed with $25 \%$ and $75 \%$ more arginine in both phases of the growth trial had significantly higher crude protein content of breast muscle than the control group and comparable with finisher period supplemented groups $\left(\mathrm{T}_{4}\right.$ and $\left.\mathrm{T}_{5}\right)$. The birds fed with $75 \%$ more $\left(\mathrm{T}_{3}\right)$ arginine in the whole period of growth had significantly higher fat content of breast muscle and had comparable effect with other treatments. This could be due to the fact that increasing arginine in broiler diets up to $168 \%$ increased mRNA concentrations for lipogenic genes in muscle. $\mathrm{Yu}$ et al., (2018) observed that Arginine increased the amino acid concentrations of breast muscle at hatch, 7- and 21-day post-hatch which might be associated with the enhancement of protein deposition. The concentration of arginine has ability to change partitioning of energy by differentially regulating expression of lipogenic genes in skeletal muscle and white adipose tissue in a way that favored lipogenesis in muscle (Ebrahimi et al., 2014).

In the present study we found that crude protein content of breast muscle was significantly $(\mathrm{p}<0.05)$ higher $(85.00$ Vs. 81.72 $\%)$ in groups fed with excess arginine from day old to slaughter $\left(\mathrm{T}_{2}\right.$ and $\left.\mathrm{T}_{3}\right)$. However, the fat content of breast muscle was significantly ( $\mathrm{p}<0.05)$ higher (3.04 Vs. $2.63 \%)$, only in birds fed $175 \%$ arginine in both starter and finisher period $\left(\mathrm{T}_{3}\right)$ than control and was comparable with $\mathrm{T}_{2}, \mathrm{~T}_{4}$ and $\mathrm{T}_{5}$ treatment groups. To concur, higher level of arginine supplemented groups showed significantly higher crude protein and fat percentages of breast muscle. But for the highest $\%$ crude protein content, $25 \%$ or $75 \%$ more arginine supplementation than the control basal diet from the starter phase is recommended. 
Table.1 Feed ingredient composition (\%) of the broiler chicken starter diet (0-3 weeks)

\begin{tabular}{|l|l|l|l|l|l|}
\hline Ingredient & $\mathrm{T}_{1}$ & $\mathrm{~T}_{2}$ & $\mathrm{~T}_{3}$ & $\mathrm{~T}_{4}$ & $\mathrm{~T}_{5}$ \\
\hline Maize grain & 53.00 & 53.00 & 53.00 & 53.00 & 53.00 \\
\hline Soyabean meal & 33.68 & 33.68 & 33.68 & 33.68 & 33.68 \\
\hline Dry fish & 5.00 & 5.00 & 5.00 & 5.00 & 5.00 \\
\hline Palm oil & 4.00 & 4.00 & 4.00 & 4.00 & 4.00 \\
\hline Mineral mixture* & 2.00 & 2.00 & 2.00 & 2.00 & 2.00 \\
\hline Common salt & 0.25 & 0.25 & 0.25 & 0.25 & 0.25 \\
\hline L- Lysine & 0.09 & 0.09 & 0.09 & 0.09 & 0.09 \\
\hline DL- Methionine & 0.20 & 0.20 & 0.20 & 0.20 & 0.20 \\
\hline L-Arginine & 0.00 & 0.39 & 1.17 & 0.00 & 0.00 \\
\hline Feed additive** & 0.61 & 0.61 & 0.61 & 0.61 & 0.61 \\
\hline Saw dust & 1.17 & 0.78 & 0.00 & 1.17 & 1.17 \\
\hline Calculated nutrient density & & & & & \\
\hline MIE (kcal / kg) & 3086 & 3086 & 3086 & 3086 & 3086 \\
\hline Crude protein (\%) & 22.22 & 22.22 & 22.22 & 22.22 & 22.22 \\
\hline Calcium (\%) & 1.01 & 1.01 & 1.01 & 1.01 & 1.01 \\
\hline A vailable & 0.53 & 0.53 & 0.53 & 0.53 & 0.53 \\
\hline phosphorous (\%) & 1.56 & 1.95 & 2.73 & 1.56 & 1.56 \\
\hline Lysine (\%) & & 1.30 & 1.30 & 1.30 & 1.30 \\
\hline Methionine (\%) & 0.58 & 0.58 & 0.58 & 0.58 \\
\hline Arginine (\%) & 0.58 & & & & \\
\hline
\end{tabular}

*Mineral mixture: each $\mathrm{kg}$ of diet supplied with $6.40 \mathrm{~g}$ Calcium, $1.20 \mathrm{~g}$ Phosphorous, $55 \mathrm{mg}$ Manganese, $2 \mathrm{mg}$ Iodine, $52 \mathrm{mg}$ Zinc, $2 \mathrm{mg}$ Copper and $20 \mathrm{mg}$ Iron,

**Feed Additives : Vitamin $\mathrm{AB}_{2} \mathrm{D}_{3} \mathrm{~K}-0.03 \%$, Ultra Vit-M $-0.05 \%$, Coccidiostat $-0.050 \%$, Perivac plus (each $200 \mathrm{~g}$ contains Vitamin E $20 \mathrm{~g}$, Biotin $160 \mathrm{mg}$, Selenium $50 \mathrm{mg}$ and carrier) $-0.050 \%$, Choline chloride $-0.40 \%$, Probiotic $-0.03 \%$. 
Table.2 Feed ingredient composition (\%) of the broiler chicken finisher diet (4-6 weeks)

\begin{tabular}{|l|c|c|c|c|c|}
\hline Ingredient & $\mathrm{T}_{1}$ & $\mathrm{~T}_{2}$ & $\mathrm{~T}_{3}$ & $\mathrm{~T}_{4}$ & $\mathrm{~T}_{5}$ \\
\hline Maize grain & 57.00 & 57.00 & 57.00 & 57.00 & 57.00 \\
\hline Soya bean meal & 28.00 & 28.00 & 28.00 & 28.00 & 28.00 \\
\hline Dry fish & 5.50 & 5.50 & 5.50 & 5.50 & 5.50 \\
\hline Palm oil & 5.50 & 5.50 & 5.50 & 5.50 & 5.50 \\
\hline Mineral mixture* & 2.00 & 2.00 & 2.00 & 2.00 & 2.00 \\
\hline Common salt & 0.25 & 0.25 & 0.25 & 0.25 & 0.25 \\
\hline DL - Methionine & 0.18 & 0.18 & 0.18 & 0.18 & 0.18 \\
\hline L-Arginine & 0.00 & 0.34 & 1.02 & 0.34 & 1.02 \\
\hline Feed additive** & 0.55 & 0.55 & 0.55 & 0.55 & 0.55 \\
\hline Saw dust & 1.02 & 0.68 & 0.00 & 0.68 & 0.00 \\
\hline Calculated nutrient density & & & & & \\
\hline MIE (kcal / kg) & 3228 & 3228 & 3228 & 3228 & 3228 \\
\hline Crude protein (\%) & 20.02 & 20.02 & 20.02 & 20.02 & 20.02 \\
\hline Calcium (\%) & 1.01 & 1.01 & 1.01 & 1.01 & 1.01 \\
\hline A vailable phosphorous & 0.54 & 0.54 & 0.54 & 0.54 & 0.54 \\
\hline (\%) & & & & & \\
\hline Lysine (\%) & 1.12 & 1.12 & 1.12 & 1.12 & 1.12 \\
\hline Methionine (\%) & 0.54 & 0.54 & 0.54 & 0.54 & 0.54 \\
\hline Arginine (\%) & 1.37 & 1.71 & 2.40 & 1.71 & 2.40 \\
\hline Mingen
\end{tabular}

*Mineral mixture: Each $\mathrm{kg}$ of diet supplied with $6.4 \mathrm{~g}$ Calcium, $1.2 \mathrm{~g}$ Phosphorous, $55 \mathrm{mg}$ Manganese, $2 \mathrm{mg}$ Iodine, $52 \mathrm{mg}$ Zinc, $2 \mathrm{mg}$ Copper and $20 \mathrm{mg}$ Iron.

**Feed Additives : Vitamin $\mathrm{AB}_{2} \mathrm{D}_{3} \mathrm{~K}-0.01 \%$, Ultra Vit-M $-0.01 \%$, Coccidiostat $-0.050 \%$, Perivac plus (each $200 \mathrm{~g}$ contains Vitamin E $20 \mathrm{~g}$, Biotin $160 \mathrm{mg}$, Selenium $50 \mathrm{mg}$ ) - $0.050 \%$, Choline chloride $-0.40 \%$, Probiotic $0.03 \%$

Table.3 Effect of dietary supplementation of excess level of arginine on chemical composition

(\% on DM basis) of breast muscle of broiler chicks (Mean* \pm SE)

\begin{tabular}{|l|c|c|c|c|c|}
\hline & Control $\mathrm{T}_{1}$ & \multicolumn{4}{|c|}{$\mathrm{L}$-arginine supplemented group } \\
\cline { 3 - 7 } Parameter & & $\mathrm{T}_{2}$ & $\mathrm{~T}_{3}$ & $\mathrm{~T}_{4}$ & $\mathrm{~T}_{5}$ \\
\hline Moisture & 73.97 & 74.62 & 73.87 & 73.95 & 74.16 \\
\hline & \pm 0.64 & \pm 0.48 & \pm 0.55 & \pm 0.77 & \pm 0.46 \\
\hline Dry matter & 26.03 & 25.37 & 26.13 & 26.04 & 25.50 \\
& \pm 0.64 & \pm 0.48 & \pm 0.55 & \pm 0.77 & \pm 0.60 \\
\hline Crude protein & $81.72^{\mathrm{a}}$ & $85.04^{\mathrm{b}}$ & $85.00^{\mathrm{b}}$ & $83.91^{\mathrm{ab}}$ & $82.62^{\mathrm{ab}}$ \\
& \pm 0.26 & \pm 1.52 & \pm 0.88 & \pm 0.51 & \pm 0.67 \\
\hline Crude fat & $2.63^{\mathrm{a}}$ & $2.76^{\mathrm{ab}}$ & $3.04^{\mathrm{b}}$ & $2.89^{\mathrm{ab}}$ & $2.94^{\mathrm{ab}}$ \\
& \pm 0.08 & \pm 0.09 & \pm 0.15 & \pm 0.12 & \pm 0.12 \\
\hline
\end{tabular}

* Mean of 3 samples.

${ }^{\mathrm{ab}}$ Means with different superscripts in a row differ significantly $(\mathrm{p} \leq 0.05)$ 
Likewise, for the highest intra muscular fat percentage, $75 \%$ more arginine supplementation from the starter phase is recommended.

\section{Research category}

Poultry nutrition, Broiler chicks lipid metabolism modulator.

\section{Acknowledgement}

Post graduate research scholars, Faculties of animal nutrition department, Madras veterinary College, TANUVAS

\section{Name of chairperson of research}

Dr. C. Bandeswaran, Ph.D., Professor.

\section{University}

Tamilnadu Veterinary and Animal Sciences University

Research project name or number: [NIL]

\section{Author contributions}

All author equally contributed

\section{Author statement}

All authors read, reviewed, agree and approved the final manuscript

\section{Conflict of Interest}

None declared

\section{Ethical approval}

This article does not contain any studies with human participants or animals performed by any of the authors.

\section{References}

Al-Daraji, H.J. and A.M. Salih, 2012a. Effect of dietary L-arginine on carcass traits of broilers. Research Opinion in Animal and Veterinary Sciences, 2: 40-44.

Al-Daraji, H.J., A. A. Al-Mashadani, W. K. Al-Hayani, A. S. Al-Hassani and H. A. Mirza, 2011. Influence of in ovo injection of L-arginine on productive and physiological performance of quail. Research Opinion in Animal and Veterinary Sciences, 1: 463-467.

AOAC, 2005. Official Methods of Analysis, $18^{\text {th }}$ edn. Association of Official Analytical Chemists, Washington, D.C., USA.

Ball, R.O., K.L. Urschel and P.B. Pencharz, 2007. Nutritional consequences of interspecies differences in arginine and lysine metabolism. Journal of Nutrition, 137: 1626- 1641.

BIS, 2007. Indian Standard: Poultry FeedsSpecification. IS: $1374-2007 . \quad 5^{\text {th }}$ Revision. Manak Bhavan, 9, Bhadur Zafar Marg, New Delhi-110002.

Ebrahimi, M., Zare Shahneh, A., Shivazad, M., Ansari Pirsaraei, Z., Tebianian, M., Ruiz-Feria, C.A. and Mohamadnejad, F. (2014) The effect of feeding excess arginine on lipogenic gene expression and growth performance in broilers. $\mathrm{Br}$. Poult. Sci., 55: 81-88.

Fernandes, J.I.M., A.E. Murakami, E.N. Martins, M.I. Sakamoto, E.R.M. Garcia, 2009. Effect of arginine on the development of the pectoralis muscle and the diameter and the protein: deoxyribonucleic acid rate of its skeletal myofibers in broilers. Poultry Science, 88(7): 1399-1406.

ICAR, 2013. Nutrient requirement of poultry. Indian Council of Agricultural Research, New Delhi.

Jiao, P., Y. Guo, X. Yang and F. Long, 2010. Effects of dietary arginine and 
methionine levels on broiler carcass traits and meat quality. Journal of Animal and Veterinary Advances, 11: 1546-1551.

Khajali, F., M. Tahmasebi, H. Hassanpour, M. R. Akbari, D. Qujeq and R. F. Wideman, 2011. Effects of supplementation of canola meal-based diets with arginine on performance, plasma nitric oxide, and carcass characteristics of broiler chickens grown at high altitude. Poultry Science, 90: 2287-2294.

Kobzik, L., M.B. Reid, D.S. Bret and J.S. Stamler, 1994. Nitric oxide in skeletal muscle. Nature, 372: 546-548.
NRC (1994). Nutrient requirements of poultry. $9^{\text {th }}$ ed. (revised). National Academy press, Washington, DC.

Stamler, J.S. and G. Messner, 2001. Physiology of nitric oxide in skeletal muscle. Physiological review, 81(1): 209-237.

Wu, L.Y., Y.J. Fang and X.Y. Guo, 2011. Dietary L-arginine supplementation beneficially regulates body fat deposition of meat-type ducks. British Poultry Science, 52: 221-226.

Yu, L. L., Gao, T., Zhao, M. M., Lv, P. A., Zhang, L., Li, J. L., and Zhou, G. H. (2018). Effects of in ovo feeding of Larginine on breast muscle growth and protein deposition in post-hatch broilers. animal, 1-8.

\section{How to cite this article:}

Sathyapriya, A., C. Bandeswaran, R. Karunakaran and Shamsudeen, P. 2018. Effect of Higher Dietary L-Arginine Supplementation on Chemical Composition of Breast Muscle in Broiler Chicken. Int.J.Curr.Microbiol.App.Sci. 7(04): 1210-1216. doi: https://doi.org/10.20546/ijcmas.2018.704.134 